\title{
Jolanta Klimek
}

Katolicki Uniwersytet Lubelski Jana Pawła II

\section{Z FONETYKI LISTÓW SWIĘTE ${ }^{O}$ OYCA PARTHENIUSZA (1643)}

Wśród nieopisanych regionalnych odmian historycznej polszczyzny jest ta udokumentowana w XVII-wiecznych polonikach kijowskich. W latach 1633-1698 nakładem drukarni działającej przy Ławrze Kijowsko-Peczerskiej ukazało się kilkanaście tekstów zróżnicowanych genologicznie i tematycznie. Wyszły one spod ręki duchownych związanych z Kolegium Mohylańskim i w dużej mierze nawiązują do konfesji autorów i tematów zaprzątających wielkie umysły epoki. Janusz Rieger, jak i wielu innych badaczy, jednoznacznie stwierdza, iż „pisarze ruscy doskonale władali językiem polskim, niewątpliwie takim, jakiego używano wówczas na kresach Rzeczypospolitej” [Rieger 2005: 197]. I tu pojawia się pytanie, jaki to był język? Czy to odmiana kresowa - jeśli tak, to która (południowa czy północna ${ }^{1}$ ), jeśli nie - to czy można tę polszczyznę określać mianem (nierozpoznanej dotychczas) odmiany polszczyzny regionalnej? Prowadzone przeze mnie badania nad polonikami kijowskimi stawiają za cel uzupełnienie wiedzy na temat regionalnych odmian dawnej polszczyzny, co postulowano już przed wielu laty. Mają także dać odpowiedź na pytanie o powinowactwa polszczyzny kijowskiej z innymi odmianami regionalnymi języka polskiego, zwłaszcza północnokresową ${ }^{2}$ i ujawnić swoiste cechy polszczyzny (tu: fonetyki) Kijowa. Komparacja kodu kijowskiego z północnokresowym jest szczególnie ważna w kontekście genezy tego pierwszego i powiązania z zewnętrzną historią języka: funkcjonowaniem Kijowa w granicach Wielkiego Księstwa Litewskiego (przed unią lubelską).

Jednym z poloników kijowskich są frapujące LISTY SWIĘTE OYCA PARTHENIUSZA Z MIEOSIERDZIA BOZEGO ARHIEPISKOPA KONSTANTINOPOLSKIEGO NOWEGO RZYMU $Y$ ICCUMENICI PATRIARCHE PISANE DO IASNIE PRZEWIELEBNEGO W BOGU IE MCI OYCA

\footnotetext{
${ }^{1} \mathrm{Na}$ ten temat, głównie w kontekście terminologiczno-geograficznym, pisałam w artykule Status polszczyzny kijowskiej w świetle granic i zasięgów polszczyzny kresowej [Klimek 2010].

${ }^{2}$ Opracowania nie tylko sporadycznie podejmują problematykę powinowactwa polszczyzny Kijowa z rozpoznanymi odmianami kresowymi, ale i unikają odpowiedzi na pytanie, z którą częścią Kresów Wschodnich należy historycznie wiązać ziemię kijowską, por. [Klimek 2010].
} 
PIOTRA MOHIEY..., wydane w 1643 roku$^{3}$. Druk, poza wierszem wstępnym Na potwarce i Przedmowa do czytelnika, zawiera polską wersję dwóch listów Parteniusza I do Piotra Mohyły oraz cerkiewne pisma patriarchów Jeremiasza I i Jeremiasza II, o których niżej. O powodach napisania listów przez patriarchę Konstantynopola czytelnik dowiaduje się trzykrotnie: ze strony tytułowej, z Przedmowy do czytelnika, wreszcie z pierwszego listu Parteniusza, m.in.:

LISTY [...] W KTORYCH znosisie potwarz włożoná przedkilką lat ná Cerkiew S. Wschodnią przez wydrukowanie Xiążki Kalwinskiey nauki pod imieniem S. pámięći Nieboszczyká Oyca Cyrilla Pátriarchi Konstántinopolskiego [s. tyt.];

Lat temu kilka mineło, iako paszkwil polskim ięzykiem, iakoby wyznania Cerkwie S. Wschodniey pod imieniem S. pámięći Nieboszczyká Cyrilla Pátriarchy Konstántinopolskiego iest z druku wydany [...] sám S. pámięći Nieboszczyk Cyrillus Pátriarcha Konstantinopolski dowiedźiawszy się o tym, zaráz publice się o ten podmiot, á imie swoie, y wszystkiey Cerkwie S. z tego fałszerza zdarł. Toż uczynił y teraznieyszy S. Ociec Patriarcha Konstántinopolski PARTHENIUS, ktory zebrawszy Synod Swoy zwyczayny, te Capita iako Hæretika á nie orthodoxa, wszystkiey Cerkwi ogłosił, fałszerza cum suis complicibus, oddawszy wiecznemu przeklęstwu : iako dostatecznie o tym z Listow Swiętobliwośći onego Czytelniku łáskawy wyrozumiesz [A2-A2v].

Cyryl I Lukaris, o którym tu mowa, w 1629 roku opublikował w Genewie łacińskie dzieło Confessio Fidei Orthodoxae zawierające idee kalwinizmu. W następnych latach ukazały się kolejne wydania pod zmienionym tytułem w językach łacińskim, greckim, niemieckim, francuskim i angielskim ${ }^{4}$, nie udało mi się, niestety, potwierdzić informacji z Listów..., jakoby Wyznanie wiary... miało także wersję polskojęzyczną. Listy Parteniusza stanowią swoiste dementi poglądów, które w swoim Confessio miał wyłożyć Cyryl I. Literatura przedmiotu milczy na temat pochodzenia polskich listów. Trudno też znaleźć informacje o ich autorze, patriarsze Konstantynopola Parteniuszu I. Mała wzmianka źródłowa na jego temat znajduje się u Jana Stradomskiego, który cytuje Dubowicza: „...i teraźniejszy ociec Parthenius nieuk, a prawie analphabeticus homo, jako od samych dostało mi się słyszeć ich duchownych" [Stradomski 2003: 250]. Nieznany jest autor przekładu tych listów - o tym bowiem, że mamy do czynienia z translacją, dowiadujemy się już ze strony tytułowej:

[...] á ná przestrogę wszystkim Práwosłáwnym posłuszeństwa S. Oyca Pátriarchi Konstántinopolskiego Synom ná Polski ięzyk przełożone y wydane [s. tyt.].

Nie można wątpić, że tłumaczem listów Parteniusza I na język polski musiała być osoba blisko związana z Ławrą Kijowską. Czy sam Mohyła przetłumaczył listy? Za tą hipotezą mogłoby przemawiać kilka faktów: chęć porozumienia między Rzymem a Konstantynopolem, troska o czystość doktryny prawosławnej i wreszcie sformu-

${ }^{3}$ Wszystkie cytaty za pierwodrukiem: Ossolineum, XVII-3757-II. Rezygnuję z rozróżniania $\int$ is, pozostałe cechy (orto)grafii bez zmian.

${ }^{4}$ Informacje za portalem Ecumenical Patriarchate of Constantinople: http://www.ec-patr.org (dostęp: 28.12.2012). 
łowanie, przyjętego kilka lat wcześniej na synodzie kijowskim, wyznania wiary prawosławnej (druk w 1643 roku) [Banaszak 1989: 79]. Wreszcie to w Lithosie Euzebiego Pimina znaleźć można informacje o genezie anatemy i jej translacjach:

nie dawno wydána Klątwá od Cerkwie Konstántinopolskiey zá starániem Cerkwi nászey Ruskiey, ná wszystkie Kálwinskie Hæretyckie Artykuły Wiáry wydáne fałszywie pod Imieniem Swiętey Pámięći Oycá Cyrillá Pátriárchy Konstántinopolskiego ná oszukánie Wiernych Bożych Synow Cerkwie Wschodniey do ktorey Klątwy wszyscy Pásterze nászy Práwosławni podpisáli się. Tá Synodálna Klątwá naypierwey do Pasterzá nászego Je ${ }^{\circ}$ Mśći Oycá Metropolity iest przynieśiona á potym w Mołdáwskiey Ziemi w Jássiech z Drukárni Hospodárskiey po Græcku wydána, potym záś zá roskazániem Je ${ }^{\circ}$ Mśći Oycá Metropolity nászego ná Polski ięzyk przełożona y z Druku wydána [Pimin 1644: 381].

Mohyła, skrupulatnie ukrywający pod pseudonimem (i w narracji) autorstwo Lithosa, przyznaje się tu de facto do swojego udziału w przekładzie listów z anatemą - to on w 1642 roku zasiadał na metropolii kijowskiej.

Listom Parteniusza I, które analizuję, towarzyszą w starodruku przechowywanym w Zakładzie im. Ossolińskich cerkiewne listy patriarchy Jeremiasza. Fakt, iż jeden z nich adresowany jest do Konstantego Wasyla Ostrogskiego, wojewody kijowskiego, marszałka hetmana wołyńskiego, starosty włodzimierskiego ${ }^{5}$, świadczy, że nadawcą musiał być zarządzający wówczas Cerkwią Jeremiasz I (1522-1545). Pod kolejnym listem, także z nagłówkiem wskazującym na autorstwo Jeremiasza, widnieje data 1583, de facto oznacza to więc, że autorem był już kolejny patriarcha - Jeremiasz II. Teksty Jeremiasza I i Jeremiasza II są podane w wersji cerkiewnej, a karty z nimi niekonsekwentnie numerowane według kanonów cerkiewnych, co każe przypuszczać, że przypadkowo - lub tylko ze względu na instytucjonalnego nadawcę - zostały spięte łącznie (we Lwowie) i opatrzone jedną sygnaturą.

$\mathrm{W}$ artykule zostały poddane analizie odzwierciedlone w pisowni Listów... wybrane cechy fonetyczne XVII-wiecznej polszczyzny kijowskiej, przedstawione w dotychczasowej literaturze przedmiotu. Ze względu na niewielkie rozmiary tekstu źródłowego - niespełna siedem kart - podawać będę pełną dokumentację form rzadszych i nieregularnych, a w wypadkach notacji wyjątkowych (tak na tle kresowym, jak i ogólnym XVII-wiecznym) także dane statystyczne.

\section{WOKALIZM}

Wariantywność fonetyczna i morfonologiczna zaobserwowana we wszystkich polonikach kijowskich jest bardzo wyraźna. W związku ze sporami co do kierunku wypierania form starszych można rozpatrywać obecne w drukach oboczności każdy - kożdy - káżdy (por. ukr. кожний), poświadczone w kolejnych kijowskich tekstach.

${ }^{5}$ W liście pojawia się ruskie imię Gienadij. 
Zdaniem Jana Petra, przy usuwaniu form starszych należy brać pod uwagę nie tylko wpływ czeszczyzny, ale i „uzus tekstów religijnych” [Petr 1957: 48]. Analiza Listów... mogłaby więc dostarczyć niezmiernie ciekawych wniosków - wszak są to teksty niewątpliwie religijne - niestety, zaimek káżdy występuje w nich bardzo rzadko. Jego jednorazowe użycia mają postaci każdy i kożdy.

\section{Realizacja samogłosek nosowych}

Eksploracja poprowadzona w tym kierunku wskazuje powinowactwa polszczyzny kijowskiej z najbliższymi jej geograficznie odmianami północno- i południowokresową. Zofia Kurzowa [2006] i Alicja Pihan-Kijasowa [1999] na Kresach północno-wschodnich, a Ewa Wolnicz-Pawłowska [2003] na Chełmszczyźnie zauważyły pewne tendencje poświadczone także w Listach...:

1) rozkład (asynchroniczna artykulacja) ę, $q>e m$, en przed wargową lub zębową: potempieni, przeklientego;

2) synchroniczna wymowa połączeń samogłoska + spółgłoska nosowa (wtórna nazalizacja antycypacyjna), por. [Kość 1999: 97]: przeklęstwu;

3) wtórna nazalizacja ${ }^{6}$ niezależnie od pozycji w wyrazie i otoczenia fonetycznego: pokućię, ucżęśnicy, nąuki, więrząc, potępięnie;

4) denazalizacja $e ̨>e$, zarówno w wygłosie: szate, imie, sie (18x), miedzy (3x), nauke $(4 \mathrm{x})$, one, wiare, figure, zasie $(4 \mathrm{x})$, poczware, swoie $(2 \mathrm{x})$, cene $(3 \mathrm{x})$, jak i przed sonorną: mineło, przyieli oraz przedniojęzykową: Naświetszego.

\section{Samogłoski pochylone}

Zapisy typu: namniy, nimasz świadczą o obecności w odmianie kijowskiej pochylonego é, znanego pobliskiej polszczyźnie północnokresowej, o czym piszą Iryda Grek-Pabisowa i Irena Maryniakowa [1997: 40-41], i polszczyźnie Lwowa, por. np. [Kurzowa 2006a]. W Listach... pochylenie konsekwentnie zapisywane jest fonetycznie, nigdy zaś przez kreskowanie é. Zastanawiać może tylko użyta w wierszu $\mathrm{Na}$ potwarcę forma zaćimiasz. Kontekst podpowiada, że należy ją odczytywać jako ścieśnioną postać czasownika zaciem(n)iasz:

Zaćimiasz Cerkiew świętą ále oná,

Jasná iest w sobie lub y zasłoniona [A1v].

Uderzającą cechą poloników kijowskich - w odniesieniu do systemu północnokresowego - jest realizowanie w nich pochylenia samogłoski $a$. Jak wykazały badania próby Lithosa Mohyły [Klimek 2010a], pod względem realizacji w druku $a$ i å Kijów zachowuje pewną odrębność od pozostałych dzielnic Polski połowy XVII wieku.

${ }^{6}$ Barbara Smolińska pokazuje przykłady podyktowane działaniem bezpośrednim lub z odległości spółgłoski nosowej, lecz zauważa u Poczobuta także realizacje analogiczne do przytaczanych przeze mnie [Smolińska 1983: 24-25]. 
W kilku kategoriach widoczne jest powinowactwo z Małopolską, w innych z Kresami, w niektórych zaś ziemia kijowska stanowi swoiste ogniwo pośrednie. Oto jak w kilku sytuacjach oznaczana jest barwa samogłoski $a^{7} \mathrm{w}$ analizowanych tu Listach...:

1) przymiotniki i imiesłowy rodzaju żeńskiego, np.: włożoná, jasná, ćiemná, żadná, świętá, Boská, pánská, wielká, wyrażoná, nápelnioná, Apostolska, Wschodnia, widoma, Boża, Christusowa, Luteránska; 26 form ma w końcówce á, natomiast $13 a$;

2) spójnik á: $100 \%$ zapisów z á;

3) rzeczownik odsłowny z -ánie, np.: wydrukowanie, zamieszanie, przepowiadanie, Stáránie, pifániem, wyznánie, mieszkánie, uraganiu, zatrzymaniu; 13 form z á, $8 \mathrm{z}$ a;

4) zakończenie imiesłowu -awszy: zostáwszy, przeczytáwszy (2x), dowiedżiáwszy się, zebrawszy, oddawszy, wyrozumiawszy; 4 zapisy z á jasnym, 3 z pochylonym $a$;

5) morfem stopnia najwyższego przymiotników náj-: náymiłszym, náymilszego, náymilszych, náyprędzey, przenáyświętszey, náymilszemi, naymiłszych; 6 notacji $\mathrm{z}$ samogłoską jasną, jedna z pochyloną;

6) morfem stopnia najwyższego przymiotników na-: zawsze z á jasnym: námniy, náświetszego, námniey, Náświętszey (2x), Náświętszy;

7) przyimek dla: zawsze z a pochylonym;

8) zakończenie bezokolicznika -áć: zawsze z a pochylonym, np.: biegać, przodkować, przydawać, uymować, imponować, czytać, zostawać;

9) morfem -áją(c), m.in.: powstáwáia, zamykáiąc, niemáią, trzymáią, máiąc, oświadczáiąc, oddalając, zabrániaiąc, postrzegaiąc, udaiąc, bywaia, oddaią, zaszczycaia, niedochowywaia, powiadają; 9 zapisów $\mathrm{z}$ á jasnym wobec $18 \mathrm{z}$ a pochylonym;

10) zaimki nas, was: wás, nás (4x); pojedyncza notacja z pochylonym $a$, cztery z á jasnym.

Ustalenie odsetka błędnych zapisów ála w każdej z wymienionych kategorii i porównanie wyników z danymi z Lithosa Mohyły i statystyką Alicji Pihan-Kijasowej [1999: 77, 80] dla czterech obszarów dialektalnych przynosi zaskakujące rezultaty. Tłumacz/składacz Listów... zawsze popełnia błąd przy oznaczaniu barwy $\{a\}$ w: superlatywie przymiotników i przysłówków z genetycznie ruskim na- i w bezokolicznikach na -áć. Na żadnym z przebadanych przez Pihan-Kijasową obszarów, jak również w Lithosie, nie notuje się tak dużego odstępstwa od normy - Kresy północno-wschodnie miały najwyższy procent form błędnych, odpowiednio: 34,2\% i 21,5\% [Pihan-Kijasowa 1999: 80]. Bardzo wysoki odsetek błędów występuje w Listach... także w zaimkach was, nas - 80\%, co wyraźnie odbiega od stanu w pozostałych dzielnicach: tylko Kresy północne błędnie oznaczają tu a, lecz nawet tam odsetek błędów nie jest tak wysoki (31,8\%) [Pihan-Kijasowa 1999: 77]. Nie inaczej jest w końcówkach przymiotników żeńskich (66,7\%) i zakończeniach -áją(c) $(66,7 \%)$ - stanowi to wyraźne odstępstwo od rozpoznanych terenów i Lithosa (nigdzie błędy nie przekraczały 15-17\%). W przypadku zapisu -awszy (57\% błędów) widoczna jest zbieżność Listów... i polszczyzny północnokresowej (47\% pomyłek) - pozostałe obszary

${ }^{7}$ Znakiem pełnej artykulacji jest kreskowanie, ale przy zapisie nås [B3v] można się zastanawiać, czy zecer faktycznie użył czcionki å, czy to tylko wina tuszu. 
i Lithos nie notują tu błędów [Pihan-Kijasowa 1999: 77]. Niepoprawne oznaczenia pojawiają się w analizowanym źródle wśród rzeczowników odsłownych (38\%), co także negatywnie wyróżnia ten druk (po 12\% błędów w Małopolsce i na Kresach północnych). Pozytywnie zaskakuje natomiast niewielka liczba pomyłek w superlatywach z polskim náj- (14,26\%; tylko jeden zapis), według obliczeń Pihan-Kijasowej jedynie w drukach małopolskich nie spotyka się błędów, a Kresy północne [Pihan-Kijasowa 1999: 80] i Lithos [Klimek 2010a: 262] mają 90\% notacji niepoprawnych. Nie popełnia się w Listach... błędów w zapisach á i dla. W spójniku sytuacja wygląda więc analogicznie jak w Lithosie [Klimek 2010a: 262], w przyimku natomiast jak na Kresach i w Małopolsce [Pihan-Kijasowa 1999: 77].

\section{Artykulacja $o L>u L$}

Pisownia Listów... poświadcza obecność w polszczyźnie kijowskiej zwężenia o do $u$ przed spółgłoskami sonornymi: ogułem, szczegulną. Nie zaskakują one w kontekście polszczyzny ogólnej, która w XVII wieku znała takie praktyki [Ostaszewska 2002: 45].

\section{KONSONANTYZM}

W kijovianach odnaleźć można dublety typu choć - chodź, być - bydźi im podobne, odzwierciedlające zaburzenia w realizacji wygłosowej dźwięczności. W Listach... stuprocentową frekwencję ma bezokolicznik z dźwięcznym wygłosem bydź. Bez znaczenia pozostaje otoczenie fonetyczne, gdyż zarówno w wygłosie absolutnym przed samogłoską, jak i spółgłoską występuje dźwięczna realizacja, np.: bydź utrapeniem, bydź przymowane, bydź niezbożnieyszeo. Tymczasem w Słowniku polszczyzny XVI wieku proporcje zdecydowanie przemawiają na korzyść być (5 : 1) [SXVI, 3: 13], a w Słowniku języka polskiego XVII i pierwszej połowy XVIII wieku ${ }^{8}$ (wersja online) wcale nie notuje się wariantu fonetycznego.

\section{Realizacja -er $(z)$ -}

Grupa -er $(z)$ - (zarówno pochodzenia sonantycznego, jak i $z^{\star} i r{ }^{*} y r$ ) w analizowanym tekście realizowana być może na trzy sposoby odzwierciedlające jej genezę: jako -ir $(z)-/-y r$, -er- i -er $(z)$-. Najwyższą frekwencję ma ostatni z wariantów, najmłodszy pod względem chronologicznym. Z pierwotnym -ir-l-yr-: rostyrki (2x), fatszyrskie, fałszyrsky; cztyrnastym; z -er-: Zwierchnośći. Nasycenie tekstu formami starszymi nie jest duże, wynosi 6,8\%.

\section{Wahania w zakresie $h: h^{\prime}, c h: c h '$}

Niezależnie od pozycji w wyrazie w Listach... bardzo często spotyka się $(45,8 \%$ notacji) miękkie -chi- w miejscu -chy-: Patriarchi (9x), przychilność, cechi. Jak widać, na wysoki odsetek form wpływ ma jeden wyraz, ale i on występuje w wariancie z Patriarchy. Poza tymi notacjami z miękkim -h'- również nazwisko adresata listów: Mohiła.

\footnotetext{
${ }^{8}$ Wersja online: www.sxvii.pl (dostęp: 30.12.2012).
} 


\section{Wahania $l: l$}

Niezmiernie ciekawe jest zachwianie repartycji spółgłosek $l i$ Ł w tekstach kijowskich. Iryda Grek-Pabisowa i Irena Maryniakowa, w ślad za Zofią Kurzową, piszą, że „należy [ono] do rzadko notowanych zarówno w przeszłości, jak i gwarach współczesnych" polszczyzny północnokresowej [Grek-Pabisowa, Maryniakowa 1997: 59] i przywołują cztery notacje XVII-wieczne. Tymczasem Listy... są kolejnym polonikiem dowodzącym pewnej nieregularności w tym zakresie. Zamiast l: naymiłszym, naymiłszych, zakroczyłi, łecz (2x), stołice, kłamtiwy, Kałwinskie, Prouinciałne, modłitwa, Modłitwy, policzony, publice, ałe, pubłiczney, sosłużytełey; l w miejscu ł: golębiey, napelniona, spolecznośći (2x), pelne, blogosławiony. Odsetek form błędnych w analizowanym tekście wynosi co prawda tylko nieco ponad 4,5\%, ale w zestawieniu z czterema odnalezionymi dotychczas zapisami XVII-wiecznymi ważniejsza wydaje się liczba poświadczeń w Listach... - 23.

\section{Wahania $r \check{z}: r z(\check{z})$ i miękkie $r^{\prime}$}

W drukach kijowskich odnaleźć można liczne zapisy świadczące o frykatywnej, za sprawą wsparcia substratowego, wymowie $r z>r \check{z}$, np.: niektorży, choć w wypadku tych notacji można również podejrzewać wpływ zwyczaju graficznego (kropkowane bywa $z \mathrm{w}$ dwuznakach $c z, s z$, może więc analogicznie zecer stawia kropkę nad $z \mathrm{w} r z$ ?). Alicja Pihan-Kijasowa wymienia podobne, pojedyncze przykłady [1999: 163-164], co pozostaje w zgodzie z normą ogólnopolską. Kresy utrzymały, jak twierdził Władysław Kuraszkiewicz, tę cechę nawet do XX wieku pod wpływem białoruskim i ukraińskim, [za Pihan-Kijasowa 1999: 163]. W Listach ... notuję również formę z pierwotnym $r$ (bez wskazania palatalności): Preoświeconemu - tu niewątpliwie pod wpływem ruskiego superlatywnego pre-.

\section{Wahania w zakresie palatalności innych spółgłosek}

Zakłócenia palatalności innych spółgłosek niż wymienione dotychczas - tak w zakresie zmiękczenia, jak i stwardnienia - można zauważyć w Listach... niezależnie od kontekstu fonetycznego. Konsekwentnie z miękkim - $t^{\prime}$ - zapisuje się przymiotniki konstántinopolski i horeticki, rzeczownik Horetictwa. Poza nimi spółgłoskę -t'notuję w rdzeniach: Artikułom, Artikuły, Clerikom, -r'- w Archimandrity, Cirillem, co może być wyrazem zwyczaju graficznego w zakresie pisowni zapożyczeń. Graficznie oddawana jest także miękkość - l'-, co może wskazywać na substratowe, wschodniosłowiańskie, podłoże polszczyzny kijowskiej: przeklientego, oddaliony. W Listach... spotyka się również zapisy stwardniałych spółgłosek na granicy morfemów: fałszyrsky, nieboszczykowsky, Rossyskych, KONSTANTINOPOLSKy bądź w rdzeniu: Przewelebnym, utrapeniem. Zdarza się także, że brakuje w zapisie zmiękczającego $i$, jest natomiast miękka spółgłoska: pożyću, światłośća. Zupełnie wyjątkowe jest oddanie miękkości wygłosowej spółgłoski za pomocą wydzielonej litery: przykazani zamiast przykazań, a także brak miękkości w końcówce przymiotnika - yostatnỹ.

Formy obce wykazują w pisowni częściową adaptację - obok polskich końcówek fleksyjnych mamy więc grafię oryginału łacińskiego, np.: Traditie, prcedestinowania. 


\section{Mieszanie $u$ i $w$}

W obcych grupach au, eu polonika kijowskie wykazują wariantywność zapisów $\mathrm{z} u$ i $w$. W analizowanych Listach... zapisów tego typu jest niewiele - nauka i formy pokrewne konsekwentnie występują z etymologicznym -au-, autor w dwóch postaciach: awthorem, Autorá. Przymiotnik Prouinciałne ma natomiast pisownię hiperpoprawną - w miejscu etymologicznego $w$ pojawia się $u$, por. [Pihan-Kijasowa 1999: 172].

Analiza fonetyczna Listów swięteo oyca Partheniusza wskazuje podłoże substratowe polszczyzny Kijowa i ujawnia w jej systemie pewien udział elementu ruskiego. Znajomość języka polskiego była wśród wykształconych kijowian znakomita, nie ulega jednak wątpliwości, że musiały przenikać do niego elementy ruskie, zwłaszcza w obszarach, gdzie obydwa języki były diametralnie różne. Dowody tego znajdujemy na każdym poziomie języka omawianego tekstu, nie tylko w fonetyce, która jest tu przedmiotem oglądu. W wielu dostrzeżonych osobliwościach można doszukiwać się wsparcia substratu ruskiego, wzmacnianego zapewne lokalnym pochodzeniem drukarzy (zob. [Klimek 2010a: 253-254]) i ich kompetencjami językowymi. Od lat 40. XVII wieku zaprzestano umieszczania nazwisk kierowników drukarni na stronach tytułowych tekstów [Isaevyč 2002], co stanowi pewne utrudnienie dla badaczy polszczyzny tych druków, gdyż nie pozwala odróżniać regionalnych cech twórcy i składacza tekstu. Wiadomo jednak, że po 1632 roku, gdy za sprawą Mohyły zaczęto tłoczyć polonika, w oficynie pracowali drukarze z Wilna, Lwowa i Krakowa [Isaevyč 2002]. Pamiętać należy też o tajemniczym tłumaczu Listów..., gdyż jego cechy idiolektalne również znalazły odzwierciedlenie $\mathrm{w}$ fonetyce tekstu. $\mathrm{Z}$ uwagi na to, że nie stwierdzam zasadniczych różnic w tym zakresie pomiędzy Listami... a pozostałymi polonikami, wnioskuję, że fonetyka przekładu korespondencji jest reprezentatywna dla kijowskiej polszczyzny lat 40. XVII wieku.

\section{BIBLIOGRAFIA}

Ban aszak M., 1991, Historia Kościoła katolickiego, t. 3, Warszawa.

Grek-Pabisowa I., Maryniakowa I., 1997, Język polski na Kresach pótnocno-wschodnich dawniej i dziś, [w:] I. Grek-Pabisowa (red.), Historia i współczesność języka polskiego na Kresach wschodnich, Warszawa, s. 27-109.

Is a evyč J., 2002, Ukrä̈n'ke knygovydannâ: vytoky, rozvytok, problemy, L'viv (http://litopys. org.ua/isaevych/is.htm).

Klimek J., 2010, a jasne i å pochylone w Lithosie Piotra Mohyly. Przyczynek do polszczyzny kijowskiej XVII stulecia, [w:] M. Kuźmicki, M. Osiewicz (red.), Dokument pisany $w$ badaniach historyka języka polskiego. Z badań nad grafia i fonetyką historycznej polszczyzny, Poznań-Zielona Góra, s. 251-264.

Klimek J., 2010a, Status polszczyzny kijowskiej w świetle granic i zasięgów polszczyzny kresowej, [w:] M. Kuźmicki, M. Osiewicz (red.), Żywe problemy historii języka, Poznań, s. 179-191. 
Klimek J., 2011, Polonika kijowskie - nierozpoznana odmiana polszczyzny XVII stulecia? Rekonesans, [w:] B. Dunaj, M. Rak (red.), Badania historycznojęzykowe. Stan, metodologia, perspektywy, Kraków, s. 91-101.

Kość J., 1999, Polszczyzna południowokresowa na polsko-ukraińskim pograniczu językowym $w$ perspektywie historycznej, Lublin.

Kurzowa Z., 2006, Język polski Wileńszczyzny i Kresów północno-wschodnich XVI-XX w., Kraków.

Kurzowa Z., 2006a, Polszczyzna Lwowa i Kresów południowo-wschodnich do 1939 roku, Kraków. Ostaszewska D. (red.), 2002, Polszczyzna XVII wieku. Stan i przeobrażenia, Katowice.

Petr J., 1957, Zaimek każdy w historii i dialektykach języka polskiego, Wrocław.

Pihan-Kija sowa A., 1999, Literacka polszczyzna Kresów pótnocno-wschodnich XVII wieku. Fonetyka, Poznań.

Pimin E., 1644, Lithos to iest Kamień z procy prawdy..., Kijów.

Rieger J., 2005, Kilka uwag o polszczyźnie pisarzy-Rusinów w XVII w., [w:] H. Sch mid (red.), Der Text und seine Spielarten im polnischen Barok. Bausteine zu einer Epochensynthese, München, s. 197-208.

Smolińska B., 1983, Polszczyzna pótnocnokresowa z przełomu XVII i XVIII w., Wrocław.

Stradomski J., 2003, Spory o „wiarę grecką” w dawnej Rzeczypospolitej, Kraków.

Wolnicz-Pawłowska E., 2003, Osobliwości fonetyczne w dawnych kresowych księgach sądowych i zapiskach administracyjnych, [w:] D. Buczko, M. Łesiów (red.), Z badań nad polsko-ukrainskimi powiązaniami językowymi, Lublin, s. 37-50.

SELECTED REMARKS ON THE PHONETICS OF LISTY... [LETTERS...] (1643)

ABSTRACT

This paper is devoted to a selection of issues concerning the phonetics of the $17^{\text {th }}$-century Kievan variety of Polish, analyzed in the context of the $17^{\text {th }}$-century standard Polish and its other regional varieties. Polish translations of the letters written by the Patriarch of Constantinople Parthenius I to the Kievan Metropolitan Piotr Mohyla were used as research material. The vocalic analysis covers the following aspects: the raised vowels, the reduction of $o N$ into $u N$, the alternation between $k a \dot{z} d y$ and $k o \dot{z} d y$, as well as the nasal vowel articulation. The paper also discusses the following consonantal features: the distortion in the palatalization of consonants, the phonetic realization of -ou-, -au- in borrowings, the presence of the palatalized $-c h$ ' - and the problematic spelling of $l-\ell$. No significant phonetic contrasts have been detected between Listy... ['Letters...'] and other texts written in the Kievan variety of Polish. This allows a conclusion that the phonetics of the translated letters is representative of the Kievan Polish of the 1640s. This variety, on the other hand, exhibits the influence of the standard Polish as well as of Russian, 


\section{ФОНЕТИКА ТЕКСТА LISTY SWIETE ${ }^{O}$ OYCA PARTHENIUSZA [ПИСМA...] (1643)}

\section{PEЗЮME}

Статья посвящена вопросам фонетики языка семнадцатого века Киева, рассматриваемого на фоне восточного варианта и общепольского языка. В качестве исходного материала взят польский перевод писем патриарха Константинополя Партения I митрополиту Киева, Петру Могиле. Анализ вокализма включает: суженные гласные, чередование $k a \dot{z} d y$ - kożdy и реализацию носовых гласных. Анализ консонантизма включает: нарушения мягкости согласных, судьбу -ои-, -au- в заимствованных формах, наличие мягкого -ch'-, ошибочные записи $l$ - $t$. Не обнаруживается больших различий между Письмами... и другими польскими текстами, напечатанными в XVII в. в Киеве, поэтому можно прийти к выводу, что фонетика перевода Писем... характерна для польского языка, употребляемого в то время в Киеве. В описываемом варианте языка можно найти следы воздействия как общепольского языка, так и восточнославянского субстрата.

Słowa kluczowe: XVII-wieczna polszczyzna kijowska, Piotr Mohyła, Parteniusz I, fonetyka, historia języka.

Keywords: Kievan variety of Polish $17^{\text {th }}$-century, phonetics, Mohyla, Parthenius I, history of language.

Ключевые слова: польский язык в Киеве в XVII в., фонетика, Петр Могила, Партений I, история языка. 